\title{
Estimation Of Losses From The Use Of Volume Units To Account For Natural Gas For Households In Ukraine
}

\author{
Yevhen Revtiuk* \\ Poznan University of Technology \\ Ivano-Frankivsk National Technical \\ University of Oil and Gas \\ Poznan, Poland \\ yevhen.revtiuk@put.poznan.pl
}

\author{
Maksym Bielawski \\ Razumkov Center \\ Kiev, Ukraine \\ bielawski@ razumkov.org.ua
}

\begin{abstract}
The natural gas market is characterized by a significant level of deadweight losses, which are due to the inability to apply perfect competition mechanisms during pricing. However, there are other loses to economic agents that are due to the technology used in the natural gas market. We have highlighted one of such types of losses that is characteristic of natural gas markets that use volume units to account for natural gas transmitted or consumed. Consideration of natural gas as an energy commodity, which is measured in units of energy, and the fact that the volume units of natural gas obtained from different sources have different energy values due to different physical and chemical properties, make the natural gas market, which uses the volume units, unfair. We proposed to calculate the losses of economic agents, which occurred due to the use of volume units to account for natural gas, as losses resulting from the deviation of the actual and average cost of a unit of natural gas energy in Ukraine. In case of households in Ukraine we estimated the total losses of economic agents, which occurred due to the use of volume units to account for natural gas.
\end{abstract}

Keywords-natural gas market, deadweight losses in natural gas market, accounting for natural gas consumed and transmitted, energy reform in Ukraine.

\section{INTRODUCTION}

A substantial literature in economics has examined the welfare costs of price ceilings in monopoly markets. The natural gas market is monopolistic in nature due to both a limited number of natural gas producers and a need for significant investment in the creation of infrastructure for the delivery of natural gas to the final consumer. At the same time, in many countries, natural gas is becoming a critical commodity for economic security, the suspension of which even for the short term can lead to catastrophic consequences. Thus, the discussion on the assessment of the welfare losses of price ceilings in the natural gas market (for example [1]-[3]) shifts from the theoretical discourse to the practical field of implementation of market mechanisms in the functioning of the gas market, particularly within the countries that have entered into the European Union's (EU) Third Energy Package (for example [4]-[8]). We investigate a specific aspect of distortion of fair pricing mechanisms that is characteristic of natural gas markets that use volume units (usually cubic meters (m3)) to account for natural gas. This method is technologically simple; it does not require significant costs for the installation of metering points for natural gas transmission, and has traditionally been used in the gas industry. On the other hand, this method does not take into account the fact that the final product in the gas market is the energy received by the consumer. These considerations suggest a transition to the use of energy units to account for the transmission of natural gas. We take a closer look at the indirect losses of households and natural gas suppliers in Ukraine, which are due to the use of volume units to account for natural gas.

\section{BACKGROUND}

In most economies, the natural gas market has emerged as a natural monopoly market, and Ukraine is no exception. After the collapse of the Soviet Union in 1991, Ukraine inherited energy-inefficient infrastructure and production system, and ranked third in the world in gas consumption (118 billion cubic meters (bcm) per year) [9]. The state is the owner of the main pipelines, because the privatization of the Ukrainian gas transmission system is prohibited by law. Instead, privatization of regional gas distribution companies began in 1990. The most recent round of the sale of stateowned gas distribution companies took place in 2012, resulting in about $70 \%$ of the market being owned by "Gaztek" company [9].

In 2015, following the signing of the Association Agreement with the EU, the Ukrainian government has resolutely embarked on reforms in the gas market to implement the provisions of the Third Energy Package. Entry into the European energy market in the face of Russian aggression (in 2014, the Russian Federation annexed Ukrainian Crimea and launched a military conflict in Donetsk and Luhansk regions) was considered by the government as one of the safeguards that should ensure energy security of Ukraine in the future, especially considering that during 2005-2014 the natural gas was imported exclusively from the Russian Federation. The government's determination for reforming the gas market was also driven by the requirements of the International Monetary Fund, which included the refusal from manual regulation of prices for households in the gas market.

Gas market reform began with the adoption of the 2015 Law on the gas market. The first stage was the liberalization of the retail gas market, which foresaw the destroyed monopoly of regional gas distribution companies through the application of the third party access principle, including (1) 
gas suppliers were given non-discriminatory access to the transmission network, (2) transmission companies needed to apply regulated tariffs so as to avoid any abuse of dominance [4]. Retail buyers were able to choose a company that would supply them with the natural gas. The activities of the gas distribution companies, which operate the gas distribution networks and therefore are subject to natural monopoly, are governed by the National Commission for State Regulation in Energy and Utilities (NKREKP), whose operating principles changed after 2016 [9]. To date, there are 46 gas distribution companies in Ukraine and 589 enterprises licensed to supply natural gas, 45 of which are subject to special obligations for gas supply (regulated tariff supply to households, district heating companies and religious organizations) [10]. Annual consumption of natural gas during 2014-2018 decreased from $42.6 \mathrm{bcm}$ to $32.3 \mathrm{bcm}$ (including household gas consumption from $11.2 \mathrm{bcm}$ to $10.6 \mathrm{bcm}$ ), with the share of imported gas falling from $46 \%$ to $33 \%$ [11].

The new regulatory field, on the one hand, obliges players in the natural gas market to use energy units to account for the transmitted natural gas [12]-[14]. On the other hand, it retains the established practice of setting prices in the natural gas market for a volume unit, despite the existing consensus among the stakeholders on the need to transition to energy units to account for the natural gas [15].

\section{LITERATURE REVIEW}

The rise in energy consumption pushes the countries to find cheaper, more convenient and, in recent decades, more environment friendly energy sources. Natural gas today has become such an energy source, because it is cheaper than the "green" energy and, at the same time, its combustion results in lower carbon dioxide emissions comparing to other fossil fuels.

The natural gas market consists of the upstream market and the downstream market. The upstream market includes activities related to exploration, development, production, gathering, purification and sales to wholesalers. The downstream natural gas market includes transmission, distribution and storage of natural gas [6].

The need to create a network-bound system of gas pipelines for the transmission of natural gas from producers to consumers, which requires synchronous management and is the object of critical infrastructure for economic security, has become a prerequisite for creation of a centrallycontrolled and vertically-integrated monopoly in many developing countries as well as countries in transition[16]. Therefore, the natural gas market, which, owing to the existence of market concentration, vertical foreclosure, cross-border market integration, information asymmetry and the mechanism of price formation, is an imperfection market [8]

In microeconomic analysis, deadweight losses are defined as losses incurred by economic agents as a result of deviations in prices from equilibrium [17]. In the case of energy markets, these deviations can be caused by both government action (price regulation, subsidies or tax policy [2]) and problems related to the features of the technology used, or so-called allocative costs [1]. Most researchers agree that the easiest way to reduce the losses of economic agents due to the imperfect market functioning is to liberalize it [16]. At the same time, the most ambitious project for liberalization of the energy markets was the adoption and implementation of the Third Energy Package, aiming to introduce competition principles and to integrate the energy systems of countries with different models of energy markets into a single energy space. Although the process of creating a single European energy market (EER) is ongoing (for example, Ukraine has started an entry into the EER in 2014), researchers already note some positive results. In particular, when it comes to the gas market, there is a decrease in the dependence of consumers on suppliers through reduction of the number of long-term natural gas supply contracts [5] and an increase of short-term and spot markets participants [3], a decrease in natural gas prices for all consumer categories during 2013-2017 [18], as well as a convergence of natural gas prices in the EU countries ([3], [19], [20]). From the point of view of economic theory, the main advantage of creating a common economic space is the reduction of public losses from the inefficient functioning of the gas market in 2008-2012, which was demonstrated in the annual report of the Agency for the Cooperation of Energy Regulators [21]. The losses of economic agents related to the features of the technology are usually considered as a component of the supplier's operating expenses. At the same time, while studying the processes of liberalization of the Ukrainian natural gas market, we stress that the other type of losses is associated with the use of volume units to measure the amount of consumed or transmitted natural gas in the downstream natural gas market, which had previously received little attention of researchers.

\section{METHODOLOGY AND ANALYSIS}

Ukrainian gas market is characterized by the use of volume units to account for the natural gas transmitted or consumed. This method of measurement is technologically simple, and, in the absence of a competitive gas market, completely satisfies all market participants. Considering that natural gas from different gas fields differs in terms of physical and chemical composition and, therefore, has different gross calorific value (GCV; the amount of energy that can be obtained by burning a unit of gas volume), majority of the developed countries, including the EU member states, set the price per unit of energy transmitted or consumed. Instead, the practice of using volume units distorts the market equilibrium, since consumers buy the same amount of natural gas of different origin and different GCV. Figure 1 demonstrates the deviations of the GCV of natural gas (further -- gas quality) supplied to the end consumers in Ukraine in 2017. We suggest to calculate the weighted average quality of natural gas as

$$
\text { Average }=\sum_{i=1}^{n} \frac{D_{i}}{D} * Q_{i},
$$

where $D_{i}$ is the amount of natural gas consumed in the respective period in the $\mathrm{i}$-th region, in $\mathrm{m}^{3}$, D is the total consumption of natural gas in Ukraine in the corresponding period, in $\mathrm{m}^{3}, \mathrm{Q}_{\mathrm{i}}$ is the quality of natural gas in the $\mathrm{i}$-th region in the corresponding period, in $\mathrm{kcal} / \mathrm{m}^{3}$, and $\mathrm{n}$ is the number of regions taken into account in the analysis. In this case, the price of energy received by the natural gas consumer is:

$$
P_{E}=\frac{P_{v}}{\text { Average }},
$$


where $\mathrm{P}_{\mathrm{v}}$ is the average market selling price in the natural gas retail market, in $\mathrm{UAH} / \mathrm{m}^{3}$.

We propose to define the losses of economic agents in the natural gas market arising from the use of volume units to account for consumed or transmitted natural gas similarly to the definition of deadweight losses from market imperfections, as the total losses of consumers and suppliers arising from the deviation of the unit price of energy of natural gas from the weighted average price in the corresponding period in Ukraine. In other words

$$
\text { Losses }=\sum_{i=1}^{n}\left(\mid Q_{i}-\text { Average } \mid \cdot D_{i}\right) \cdot P_{E},
$$

To perform the calculations, we used the following information:

- data on consumption of natural gas for 2017 by regions, individual consumers and months, which was received from the operator of the Ukrainian gas transmission system "Ukratransgaz" company following the information request in 2018, m3;

- indicators of the weighted average quality of natural gas by region according to the data from "Ukrtransgaz", kcal/m3 [22].

The supply of natural gas in Ukraine is formed both from imported natural gas, which amounted to $14.1 \mathrm{bcm}$ or $44 \%$ of the gas used in 2017 [11], and from own production (as of 2018, 264 permits for industrial natural gas production were issued [23]). The end consumer receives a mixture of natural gas from different sources. In 2017 the average weighted monthly gas quality by region varied from 8015 to $8529 \mathrm{kcal} / \mathrm{m} 3$ (Figure 1). At the same time, monthly deviations in gas quality within the region varied from $3.9 \%$ (Dnipropetrovsk region) to $0.7 \%$ (Ternopil region). The price of natural gas for households in Ukraine is set by the regulator (NKREKP), and in 2017 amounted to $6.879 \mathrm{UAH} / \mathrm{m} 3$.

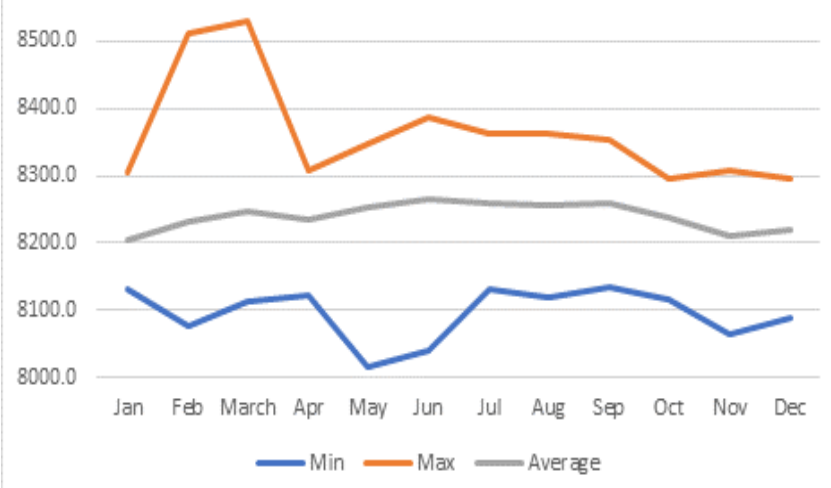

Fig. 1. Deviation of GCV of natural gas (quality of natural gas) obtained by end consumers in $2017(\mathrm{kcal} / \mathrm{m} 3)$.

Using equation (2) we calculated the average price paid by households per unit of natural gas energy per month in 2017. Figure 2 shows the price range per mcal of natural gas energy paid by households by region. The prices ranged from $0.807 \mathrm{UAH} / \mathrm{mcal}$ to $0,858 \mathrm{UAH} / \mathrm{mcal}$ during the year. The total losses of economic agents from the use of volume units to account for natural gas consumed by households in 2017 , thus, amounted to UAH 770, 35 million or $1 \%$ of the cost of natural gas consumed by households (Table 1).

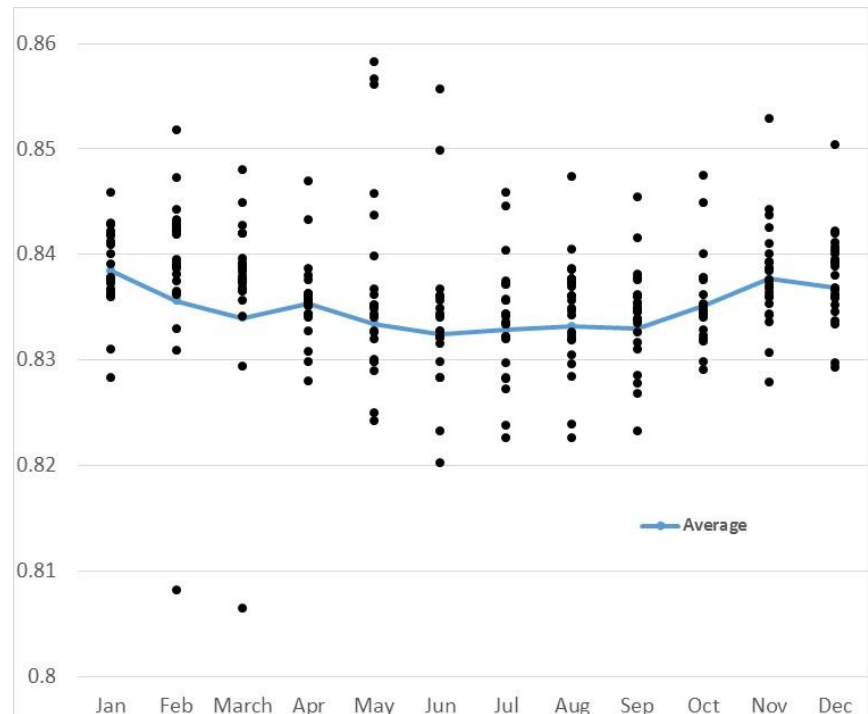

Fig. 2. Comparison of the cost of 1 mcal of natural gas paid for by households in 2017 (UAH/mcal).

\section{CONCLUSIONS AND DISCUSSION}

The natural gas market is defined by a high degree of monopolization, which is explained by both the limited number of producers in the upstream natural gas market and the need for significant investments in the transmission and distribution networks needed to supply natural gas to the end consumer. Due to these circumstances, the natural gas market is characterized by a significant level of deadweight losses, which are due to the inability to apply perfect competition mechanisms during pricing. However, there are other loses to economic agents that are due to the technology used in the natural gas market. We have highlighted one of such types of losses that is characteristic of natural gas markets that use volume units to account for natural gas transmitted or consumed. Consideration of natural gas as an energy commodity, which is measured in units of energy, and the fact that the volume units of natural gas obtained from different sources have different energy values due to different physical and chemical properties, make the natural gas market, which uses the volume units, unfair.

We proposed to calculate of the losses of economic agents (households and natural gas suppliers), which occurred due to the use of volume units to account for natural gas, as losses resulting from the deviation of the actual and average cost of a unit of natural gas energy in Ukraine. Using the example of the Ukrainian natural gas market for domestic consumers, we analyzed the deviation of the energy value of natural gas by regions in 2017 and calculated the actual cost of energy supplied to households of natural gas, which ranged from $0.807 \mathrm{UAH} / \mathrm{mcal}$ to $0,858 \mathrm{UAH} / \mathrm{mkal}$. The total losses of economic agents in the natural gas market in 2017 amounted to UAH 770,35 million or $1 \%$ of the cost of natural gas consumed by households. The identified losses suggest a need to introduce calculations for consumed and transmitted natural gas in the consumer market in energy units. 
TABLE I. THE ESTIMATES OF ECONOMIC AGENTS' LOSSES DUE TO USE OF THE VOLUME UNITS TO ACCOUNT FOR GAS CONSUMPTION BY UKRAINIAN HOUSEHOLDS IN 2017

\begin{tabular}{|c|c|c|c|c|}
\hline \multirow[b]{2}{*}{ Region } & \multirow{2}{*}{$\begin{array}{c}\text { Volume of } \\
\text { gas } \\
\text { consumption } \\
\text { mln m3 }\end{array}$} & \multirow{2}{*}{$\begin{array}{c}\text { Average } \\
\text { cost of } \\
\text { natural } \\
\text { gas, } \\
\text { UAH/ } \\
\text { mcal } \\
\end{array}$} & \multicolumn{2}{|c|}{ Losses, } \\
\hline & & & $\begin{array}{c}\text { mln } \\
\text { UAH }\end{array}$ & $\%$ \\
\hline Vannytsya & 516.27 & 0.8348 & 19.00 & 0.53 \\
\hline Volyn & 274.21 & 0.8376 & 6.73 & 0.36 \\
\hline Dnipropetrovsk & 929.78 & 0.8377 & 233.89 & 3.66 \\
\hline Donetsk & 470.08 & 0.8273 & 77.13 & 2.39 \\
\hline Zhytomyr & 378.10 & 0.8363 & 9.83 & 0.38 \\
\hline Zakarpattya & 405.83 & 0.8345 & 15.69 & 0.56 \\
\hline Zaporizhzhya & 385.64 & 0.8392 & 26.00 & 0.98 \\
\hline $\begin{array}{l}\text { Ivano- } \\
\text { Frankivsk } \\
\end{array}$ & 520.40 & 0.8364 & 15.03 & 0.42 \\
\hline Kyiv & 1065.59 & 0.8301 & 41.47 & 0.57 \\
\hline Kirovohrad & 252.56 & 0.8355 & 12.20 & 0.70 \\
\hline Luhansk & & 0.8375 & 19.66 & 1.11 \\
\hline Lviv & 845.40 & 0.8415 & 51.67 & 0.89 \\
\hline Mykolaiv & & 0.8437 & 17.76 & 0.91 \\
\hline Odesa & 501.35 & 0.8363 & 26.14 & 0.76 \\
\hline Poltava & 589.52 & 0.8365 & 18.15 & 0.45 \\
\hline Rivne & 301.62 & 0.8350 & 6.15 & 0.30 \\
\hline Sumy & 376.33 & 0.8367 & 9.64 & 0.37 \\
\hline Ternopil & 446.03 & 0.8337 & 8.66 & 0.28 \\
\hline Kharkiv & 730.30 & 0.8360 & 70.30 & 1.40 \\
\hline Kherson & 242.01 & 0.8339 & 19.50 & 1.17 \\
\hline Khmelnytsk & 431.72 & 0.8408 & 11.77 & 0.40 \\
\hline Cherkasy & 423.56 & 0.8358 & 29.44 & 1.01 \\
\hline Chernivtsy & 275.65 & 0.8380 & 11.27 & 0.59 \\
\hline Chernihiv & 328.98 & 0.8362 & 13.27 & 0.59 \\
\hline Total & 11232.65 & & 770.35 & 1.00 \\
\hline
\end{tabular}

This study, however, has the following limitations. Such type of losses of the economic agents are peculiar and specific only to markets where volume units are still used to account for the natural gas. Transit to accounting for natural gas in energy units completely eliminates this type of losses. The proposed calculations were based on the use of a regulated price for natural gas, that is different from the market price. In Ukraine the natural gas market reforms have just begun, and the competition in both downstream and upstream markets is virtually absent. In a view of this, estimating a fair market price for natural gas is impossible, which made me choose the price of natural gas for domestic consumers as the average weighted price in the market of natural gas for domestic consumers.

\section{REFERENCES}

[1] L. Davis and L. Kilian, "The Allocative Cost of Price Ceilings in the U.S. Residential Market for Natural Gas", Journal of Political Economy, vol. 119, no. 2, pp. 212-241, 2011. Available: $10.1086 / 660124$

[2] L. Davis, "The Economic Cost of Global Fuel Subsidies", American Economic Review, vol. 104, no. 5, pp. 581-585, 2014. Available: 10.1257/aer.104.5.581
[3] C. K. Chyong, "European Natural Gas Markets: Taking Stock and Looking Forward", Rev Ind Organ, vol. 55, no. 1, pp. 89-109, Aug. 2019.

[4] European Commission, "Questions and Answers on the third legislative package for an internal EU gas and electricity market", 2011

[5] A. Neumann, S. Rüster, and C. von Hirschhausen, "Long-Term Contracts in the Natural Gas Industry - Literature Survey and Data on 426 Contracts (1965-2014) Data Documentation 77". Deutsches Institut für Wirtschaftsforschung, 2015.

[6] N. Herweg, "The European Natural Gas Market and Its Regulation", in European Union Policy-Making, Cham: Springer International Publishing, 2017, pp. 73-90.

[7] K. Talus, "Long-term natural gas contracts and antitrust law in the European Union and the United States", J World Energy Law Bus, vol. 4, no. 3, pp. 260-315i, Sep. 2011.

[8] K. Talus, Vertical Natural Gas Transportation Capacity, Upstream Commodity Contracts, and EU Competition Law. Kluwer Law International B.V., 2011.

[9] P. Rozwałka and H. Tordengren, 'The Ukrainian residential gas sector: a market untapped", Oxford Institute for Energy Studies, Jul. 2016 .

[10] "Public information", Nerc.gov.ua, 2019. [Online]. Available: http://www.nerc.gov.ua/?id=21970. [Accessed: 26- Aug- 2019].

[11] "Naftogas Group", Naftogaz.com, 2019. [Online]. Available: http://www.naftogaz.com/www/3/nakweben.nsf. [Accessed: 26- Aug2019].

[12] "NKREKP Resolution of 26.01.2017 number 84 "On Amendments to Some Resolutions NKREKP on the introduction on the market of natural gas use units of energy"", Nerc.gov.ua, 2019. [Online]. Available: http://www.nerc.gov.ua/index.php?id=23448. [Accessed: 26- Aug- 2019].

[13] "NKREKP Resolution number 2494 of 30.09.2015 "On approval of the Code gas distribution systems"", Nerc.gov.ua, 2015. [Online]. Available: http://www.nerc.gov.ua/index.php?id=18017. [Accessed: 26- Aug- 2019].

[14] "NKREKP Resolution number 2493 of 30.09.2015 "On approval of the Code gas transport system"", Nerc.gov.ua, 2015. [Online]. Available: http://www.nerc.gov.ua/index.php?id=18007. [Accessed: 26- Aug- 2019].

[15] Y. Revtiuk and O. Susak, "How to implement in Ukraine to use the energy units in the natural gas market" (in Ukrainian), The International Renaissance Foundation, Kiev, 2018.

[16] P. D. Cameron and M. Brothwood, Competition in Energy Markets: Law and Regulation in the European Union. Oxford University Press, 2007.

[17] A. Barkley, The Economics of Food and Agricultural Markets. New Prairie Press. 2019.

[18] "ACER Market Monitoring Report 2017", Agency for the Cooperation of Energy Regulators, Sep. 2018.

[19] A. Neumann and A. Cullmann, "What's the story with natural gas markets in Europe? Empirical evidence from spot trade data," in 2012 9th International Conference on the European Energy Market, 2012, pp. 1-6.

[20] C. Growitsch, M. Stronzik, and R. Nepal, "Price Convergence and Information Efficiency in German Natural Gas Markets," Ger. Econ. Rev., vol. 16, no. 1, pp. 87-103, 2015.

[21] "Annual Report on the Results of Monitoring the Internal Electricity and Natural Gas Markets in 2012", Agency for the Cooperation of Energy Regulators, Nov. 2013.

[22] “The Quality of Natural Gas" ( in Ukrainian). Utg.ua, 2019. [Online]. Available: http://utg.ua/utg/business-info/yakst-gazu.html. [Accessed: 26- Aug- 2019].

[23] "Special permits. SSPC "Geoinform Ukraine" (in Ukrainian). Geoinf.kiev.ua, 2019. [Online]. Available: http://geoinf.kiev.ua/specdozvoli/. [Accessed: 26- Aug- 2019]. 